\title{
Survei Hama Pada Perkebunan Kelapa Sawit Rakyat di Kecamatan Sembilan Koto Kabupaten Dharmasraya
}

\author{
Author(s): Nushasnita ${ }^{(1)}$; Yaherwandi ${ }^{(1)}$; Siska Efendi (1)* \\ (1) Fakultas Pertanian, Universitas Andalas \\ * Corresponding author: siskaefendi@agr.unand.ac.id
}

\author{
Submitted: 24 Des $2019 \quad$ Revised: 20 Feb 2020 Accepted: 23 Feb 2020
}

\begin{abstract}
ABSTRAK
Kelapa sawit adalah salah satu komoditas pertanian yang mempunyai peran penting dalam subsektor perkebunan di Indonesia. Tanaman kelapa sawit dapat diserang oleh berbagai hama dimulai dari pembibitan hingga tanaman yang telah dibudidayakan di lapangan. Penelitian ini bertujuan untuk mengetahui dan mempelajari hama utama pada perkebunan kelapa sawit rakyat di Kecamatan Sembilan Koto Kabupaten Dharmasraya. Penelitian dilaksanakan di Nagari Koto IV Nan Dibawah, Silago dan Banai selama 3 bulan yaitu dari bulan September sampai November 2018. Penelitian dilakukan menggunakan metode Porposive Random Sampling di kebun kelapa sawit rakyat umur 2-5 tahun dengan luas areal \pm 1 ha. Pengambilan serangga dilakukan dengan koleksi secara langsung. Pengamatan hama dilakukan satu kali dua minggu. Serangga yang didapat dipisahkan berdasarkan fungsionalnnya. Serangga yang tergolong hama diidentifikasi dilaboratorium Bioekologi Serangga Jurusan Hama dan Penyakit Tanaman Fakultas Pertanian Universitas Andalas dan Laboratorium Tanah dan Tanaman Kampus III Unand Dharmasraya. Serangga hama yang ditemukan pada penelitian sebanyak 20 spesies, 9 famili dan 4 ordo. Hama paling banyak ditemukan adalah Bothrogonia ferugenia. Persentase serangan tertinggi terdapat di Nagari Silago dengan kerusakan serangan sebesar 88,33\%, dan Intensitas kerusakan hama yaitu 9,60\%.
\end{abstract}

\section{Kata Kunci:}

Hama utama;

Kelapa sawit rakyat;

Kecamatan Sembilan Koto;

Survei;

\section{Keywords:}

Main pest;

Smallholder oil palm;

Sembilan Koto district;

Survey;

\section{ABSTRACT}

Oil palm is one of the agricultural commodities that has an important role in the plantation subsector in Indonesia. Oil palm plants can be attacked by a variety of pests, starting from nurseries to crops that cultivated in the field. This study aims to determine and study the main pests on smallholder oil palm plantations in the Sembilan Koto District, Dharmasraya Regency. The study was conducted in Nagari Koto IV Nan Dibawah, Silago, and Banai for three months, from September to November 2018. The study conducted using the Purposive Random Sampling method in smallholder oil palm plantations aged 2-5 years with an area of \pm 1 ha. Intake is carried out by direct collection. Observation of pests done once every two weeks. Insects that obtained are separated based on their function. Insects classified as pests identified in the Insect Bioecology Laboratory of the Department of Pests and Plant Diseases, Faculty of Agriculture, Andalas University and the Soil and Plant Laboratory Campus III Unand Dharmasraya. Insect pests found in the study were 20 species, nine families and four orders. The most common pest is the Bothrogonia ferugenia. The highest percentage of attacks was in Nagari Silago with attack damage of $88.33 \%$, and pest damage intensity was $9.60 \%$. 


\section{PENDAHULUAN}

Kelapa sawit adalah salah satu komoditas pertanian yang mempunyai peran penting pada subsektor perkebunan di Indonesia. Berdasarkan data Buku Statistik Perkebunan Indonesia 2014-2016, produksi kelapa sawit Indonesia tahun 2015 tercatat sebesar 31,28 juta ton. Produksi ini berasal dari 11,3 juta ha luas areal perkebunan kelapa sawit nasional (Direktorat Jenderal Perkebunan, 2015). Budidaya kelapa sawit dilakukan pada 26 dari 34 provinsi di Indonesia dengan Riau dan Sumatera Utara sebagai sentra produksi CPO terbesar di Indonesia. Kontribusi dua provinsi tersebut masingmasing sebesar 23,75\% dan 16,24\%. Peringkat berikutnya berturut-turut adalah Provinsi Kalimantan Tengah, Sumatera Selatan, Jambi dan Kalimantan Barat dengan kontribusi masing-masing sebesar $10,96 \% ; \quad 9,76 \% ; 6,39 \%$; dan $6,60 \%$. Berikutnya masih terdapat beberapa provinsi yang terus berupaya meningkatkan produksi kelapa sawit, salah satunya adalah Sumatera Barat.

Produksi tanaman kelapa sawit di Sumatera Barat dari tahun 2011 hingga 2014 yakni sebesar $354,445.70$ ton; 1,841.580 ton; 426,876 ton; dan 459,793 ton. Di Sumatera Barat terdapat dua kabupaten penghasil kelapa sawit terbesar yaitu Dharmasraya dan Pasaman Barat, dengan total produksi tahun 2015 yaitu $74,020,050$ ton dan $1,645,142.40$ ton (Badan Pusat Statistik, 2014). Luas penggunaan lahan untuk kelapa sawit di Kabupaten Dharmasraya mencapai 31,842 hektar dari total luas lahan pertanian. Pada tahun 2014 dilakukan penambahan lahan untuk perkebunan kelapa sawit sebesar 612,31 ha akan tetapi upaya tersebut belum mampu meningkatkan produksi kelapa sawit. Hal tersebut dapat dilihat pada produksi tahun 2013 yaitu sebanyak $355,457.16$ ton turun pada tahun 2014 dan 2015 menjadi 349,285.31 ton dan $340,182.60$. Penyebab turunnya produksi tersebut adalah serangan hama dan penyakit pada beberapa kecamatan sentra kelapa sawit di Kabupaten Dharmasraya.

Kelapa sawit diserang berbagai hama dari pembibitan hingga tanaman yang dibudidayakan di lapangan. Saat di lahan, hama menyerang pada fase tanaman belum menghasilkan (TBM) sampai tanaman menghasilkan (TM). Hama kelapa sawit sebagian besar adalah serangga terutama dari Ordo Coleopotera, Lepidoptera, Orthoptera, dan Isoptera. Dilaporkan (Risza, 2010), bahwa hama yang menyerang tanaman kelapa sawit adalah ulat kantung (Lepidoptera: Psychidae), kumbang tanduk (Coleoptera: Scarabaeidae), ulat api (Lepidoptera: Limacodidae). Ulat api merupakan salah satu hama yang dominan menyerang kelapa sawit. Berdasarkan data Direktorat Perlindungan Perkebunan diketahui total luas serangan hama pada perkebunan kelapa sawit tahun 2014 yaitu 78,764.31 ha, dengan ulat api dan tikus tercatat sebagai hama utamanya. Serangan hama dan penyakit dapat menurunkan produksi sampai $70 \%$. Kerugian lain yang ditimbulkan serangan hama adalah bertambahnya biaya pemeliharaan dan produksi yang harus dikeluarkan untuk memulihkan kondisi tanaman.

Kecamatan Sembilan Koto memiliki penduduk dengan rata-rata bekerja sebagai petani kelapa sawit. Dimana produksi kelapa sawit tahun 2017 yaitu sebanyak 2.499 ton (Badan Pusat Statistik Dharmasraya, 2018). Kebun kelapa sawit milik petani tidak dirawat dengan intensif. Kondisi tersebut memicu serangan hama, dan pada saat tanaman terserang hama petani tidak melakukan tindakan pengendalian. Hal tersebut disebabkan rendahnya pengetahuan petani tentang jenis hama dan cara pengendalian hama tersebut. Sebelumnya sudah dilaporkan Safitri, Yaherwandi, \& Efendi (2020) bahwa terdapat 18 spesies serangga herbivora pada perkebunan kelapa sawit 
rakyat di Kecamatan Sitiung Kabupaten Dharmasraya. Untuk informasi hama kelapa sawit di Kecamatan Sembilan Koto belum ada dilaporkan.

Survei hama pada tanaman kelapa sawit akan berperan penting dalam pengelolaan hama utama. Melalui survei tersebut dapat diidentifikasi jenis hama yang menyerang kelapa sawit di Kecamatan Sembilan Kota. Hasil survei dapat digunakan sebagai acuan dalam penentuan tindakan pengendalian yang akan dilakukan. Pengendalian tersebut akan tepat sasaran jika organisme penyebab dan faktor penting lainnya diketahui. Penelitian ini bertujuan untuk mengetahui dan mempelajari hama pada perkebunan kelapa sawit rakyat di Kabupaten Dharmasraya, khususnya Kecamatan Sembilan Koto.

\section{METODOLOGI}

\section{Waktu dan Tempat}

Pengambilan sampel serangga hama pada bulan September sampai dengan November 2018. Pengkoleksian dilaksanakan di kebun kelapa sawit rakyat yang terdapat di Nagari Koto IV Nan Dibawuah, Silago, dan Banai di Kecamatan Sembilan Koto, Kabupaten Dharmasraya, Provinsi Sumatera Barat. Serangga yang sudah dikoleksi dikoleksi diidentifikasi di laboratorium Bioekologi Serangga Jurusan Hama dan Penyakit Tanaman Fakultas Pertanian Universitas Andalas dan Laboratorium Tanah dan Tanaman Kampus III Unand Dharmasraya.

\section{Bahan dan Alat}

Bahan yang digunakan dalam penelitian ini adalah alkohol 96\% dan lem serangga. Untuk mengoleksi dan indentifikasi serangga hama digunakan beberapa alat antara lain botol koleksi, meteran, pinset, kuas, labu semprot, sarung tangan, mikroskop binokuler, jarum serangga, mikrotube, kertas label, alat tulis, thermo-hygrometer, anemometer, dan luxmeter.

\section{Metode Penelitian}

Penelitian berbentuk survei dengan metode Purposive Random Sampling untuk menentukan lokasi penelitian. Kriteria pemilihan lokasi yaitu perkebunan rakyat dengan luas \pm 1 ha dan umur 2 - 5 tahun. Pada masing - masing Nagari dipilih dua kebun kelapa sawit. Total lahan untuk pengamatan sebanyak enam petak. Pada kebun kelapa sawit ditentukan sebanyak $10 \%$ tanaman sampel dari total tanaman. Penentuan tanaman sampel menggunakan metode sistematik pada garis diagonal. Pada garis tersebut ditentukan sampel pertama, kemudian untuk sampel selanjutnya di tentukan berdasarkan jarak, yaitu jarak antara satu dengan sampel berikutnya 2 batang. Pengamatan serangga hama dilakukan pada tanaman tersebut dengan melihat semua bagian tanaman yang dapat diserang hama, mulai dari daun, batang, bunga, dann buah. Untuk serangga hama yang tidak bisa dikoleksi secara langsung maka digunakan jaring serangga untuk menangkap serangga tersebut. Pada penelitian ini hama kelapa sawit yang diamati hanya dari kelompok serangga.

\section{Pengambilan Serangga Contoh}

Pengambilan serangga contoh dilakukan dengan koleksi secara langsung dan penggunaan jaring serangga. Koleksi dilakukan dengan menundukkan pelepah kelapa sawit agar memudahkan untuk mengoleksi serangga hama yang terdapat didaun. Daun kelapa sawit yang diamati adalah pelepah ke 15, 16, dan 17 dan penentuan nomor pelepah dengan melihat filotaksis tanaman sampel. Masing-masing pelepah diamati untuk satu kali pengamatan dimulai pelepah ke 15 pada bulan pertama. Pelepah tersebut tidak dipotong atau dipatahkan karena tanaman masih berumur 2-5 tahun sehingga masih mudah untuk dijangkau. Pengamatan juga 
dilakukan pada tumbuhan paku epifit yang tumbuh dibatang kelapa sawit. Selain pada batang kelapa sawit pengamatan juga dilakukan pada gulma yang terdapat pada petak sampel yang terdapat disekitar tanaman sampel. Pengamatan tersebut dilakukan dengan menggunakan jarring serangga yang dilakukan pada tanaman sampel dengan mengayunkan jaring di udara selama \pm 10 menit. Serangga herbivora tertangkap disimpan dalam botol koleksi yang telah berisi alkohol 96\%.

\section{Sortasi dan Identifikasi Serangga Contoh}

Sortasi serangga contoh dilakukan dengan memisahkan serangga berdasarkan fungsionalnya. Serangga yang dinyatakan sebagai serangga herbivora di identifikasi di laboratorium Bioekologi Serangga Jurusan Hama dan Penyakit Tanaman Fakultas Pertanian Universitas Andalas dan Laboratorium Tanah dan Tanaman Kampus III Dharmasraya. Serangga sampel diidentifikasi sampai pada tingkat spesies dengan melihat karakteristik morfologi menggunakan buku kunci determinasi serangga (Sulthoni et al., 1991) dan (Scientific \& of Entomology, 1991), (Simanjuntak et al., 2011), dan hama dan penyakit kelapa sawit (Susanto et al., 2010).

\section{Analisi Data}

Penentuan Tingkat Serangan Hama Tiap Lokasi (\%), Penentuan tingkat serangan hama dilakukan menggunakan rumus:

$$
\mathrm{K}=\frac{n}{N} \times 100 \%
$$

Keterangan:

$\mathrm{K}$ : Persentase kerusakan tanaman pada lokasi pengamatan

$\mathrm{n}$ : Jumlah tanaman sampel yang diserang hama

$\mathrm{N}$ : Jumlah total tanaman sampel dalam satu lokasi
Penentuan Intensitas Serangan Hama Tiap Tanaman (\%), Tingkat kerusakan akibat serangan hama ditentukan dengan rumus:

$\mathrm{I}=\frac{n i . V i}{N . V} x 100 \%$

Keterangan:

I : Intensitas serangan (\%)

ni : Jumlah Pelepah dengan skor ke - i

Vi : Nilai skor serangan

$\mathrm{N}$ : Jumlah pelepah tanaman yang diamati

$\mathrm{V}$ : Skor tertinggi

Tinggi skor yang digunakan :

0 : Sehat

1 : Sangat ringan ( $1-20 \%$ pelepah rusak)

2 : Ringan ( $21-40 \%$ Pelepah rusak)

3 : Sedang (41- 60\% Pelepah rusak)

4 : Berat (61-80\% Pelepah rusak)

5 : Sangat berat (81-100\% Pelepah rusak)

\section{HASIL DAN PEMBAHASAN}

Serangga Hama Pada Perkebunan Kelapa Sawit Rakyat

Serangga hama yang ditemukan pada penelitian ini sebanyak 20 spesies, 9 famili dan 4 ordo. Ordo yang ditemukan yaitu Orthoptera, Hemiptera, Lepidoptera dan Coleoptera. Pada Ordo Orthoptera dikoleksi sebanyak dua famili yaitu Acrididae dan Tettigonidae dengan tujuh spesies. Jumlah ini lebih banyak dari pada Ordo Hemiptera yang terdiri dari tiga famili yaitu Alydidae, Cicadelidae, Coreoidae dengan lima spesies. Berikutnya pada Ordo Lepidoptera ditemukan sebanyak dua famili yaitu Lymantarianae dan Psychidae dengan lima spesies. Terakhir adalah Ordo Coleoptera yang terdiri dari dua famili yakni Metaonycha dan Crysomelidae dengan 3 spesies "(Tabel 1)". 
Tabel 1. Serangga Hama Perkebunan Kelapa Sawit Rakyat Kecamatan Sembilan Koto Table 1. Palm Oil Plantation Insect Pest Society of Sembilan Koto District

\begin{tabular}{lll}
\hline Ordo & Famili & Spesies \\
\hline Orthoptera & Acrididae & Stenocatantops splendens (Thunberg, 1815) \\
& & Tagasta marginella (Thunberg, 1815) \\
& Dissosteira pictipennis (Bruner, 1905) \\
& Mermiria bivitata (Serville, 1838) \\
& Valanga nigricornis (Burm, 1838) \\
& Dissosteria Carolina (Linnaeus, 1758) \\
& Neoconocephalus triops (Linnaeus, 1758) \\
& Tettigonidae & Bothrogonia ferruginea (Fabricius 1787) \\
Hemiptera & Cicadellidae & Physomerus grossipes (Fabicius, 1974) \\
& Alydidae & Homoeocerus relates (Distant, 1908) \\
& Coreidae & Piezogaster (Amyot \& Serville, 1843) \\
& & Lymantaria dispae (Linnaeus, 1758) \\
& & Pysche casta (Pallas, 1767) \\
Lepidoptera & Sterrhopterix fusca (Haworth, 1809) \\
& Lymantarianae & Gymnelema (Hampson, 1910) \\
& Psychidae & Sp 14 \\
& & Sp 8 \\
& & Aulocophora similis Oliver \\
Coleoptera & Epicauta hirticornis (Haag-Rutenberg, 1880)
\end{tabular}

Orthoptera merupakan ordo yang spesiesnya banyak berstatus sebagai hama pada tanaman kelapa sawit. Hal yang sama juga dilaporkan (Irwanda BB, 2018) dimana hama pada tanaman kelapa sawit di pembibittan lebih banyak dari Ordo Orthoptera. Sebelumnya dilaporkan (Fauzi et al., 2012) bahwa di temukan banyak spesies hama dari Ordo Orthoptera pada tanaman kelapa sawit. Tingginya kelimpahan Orthoptera karena ordo tersebut merupakan salah satu ordo terbesar dalam kelas Hexapoda. Dilaporkan (Borror et al., 1992) Ordo Orthoptera terdiri dari 20.000 spesies. Selain itu, sebagian besar spesies dari Ordo Orthoptera bersifat sebagai herbivora. Hanya sebagian kecil yang bersifat sebagai predator dan detrivor. Famili tanaman yang banyak digunakan sebagai tanaman inang adalah fabaceae, poaceae, dan palmae. Selain memakan tanaman yang dibudidayakan, Ordo Orthoptera juga menggunakan tanaman liar seperti gulma sebagai inangnya. Pada saat pengamatan, sebagian besar lokasi penelitian tidak melakukan pengendalian gulma. Menurut (Jaganmohan et al., 2013). jumlah Orthoptera lebih berlimpah pada wilayah pertanian yang memiliki banyak rumput dan gulma yang jarang dibersihkan. Fielding \& Brusven (1995) menyatakan bahwa vegetasi sangat mempengaruhi komposisi dan keberadaan Orthoptera dalam suatu ekosistem. Semakin tinggi keanekaragaman vegetasi pada suatu habitat maka semakin tinggi pula sumber pakan bagi Orthoptera dalam suatu habitat, sehingga keberadaanya akan melimpah (Guo, Li \& Gan, 2006) menambahkan bahwa perubahan keanekaragaman komunitas vegetasi dapat menyebabkan variasi dalam pola khusus keanekaragaman hayati Orthoptera karena menurut (Ingrisch, 2008). Orthoptera biasanya mempunyai ketergantungan khusus terhadap vegetasi dan mikroklimat. 
Spesies Orthoptera yang paling banyak ditemukan di lahan penelitian adalah famili Acrididae dan Tettigonidae. Di Indonesia tercatat \pm 51 spesies anggota famili Acrididae terdaftar sebagai hama (Sundberg et al., 2001). Sedangkan Tettigonidae adalah kelompok yang sangat besar lebih dari 7.000 spesies dalam lebih dari 1000 genus (Tjiptono, 2014) dan (Bina, 2006). Mereka ditemukan di semua benua kecuali Antartika. (Fakhrah, 2016) mengatakan dalam aspek ekonomi seringkali serangga Ordo Orthoptera menjadi permasalahan untuk masyarakat misalkan Famili Acrididae dan Gryllidae yang menjadi hama tanaman budidaya dan menyebabkan kerugian bagi manusia. Dua famili tersebut termasuk serangga herbivora yang merupakan pemakan tumbuhan dan dapat menempati hampir semua tipe habitat, baik pada daun, kanopi atau tajuk pohon dan belukar. (Ullah, 2012), bahwa belalang (Acrididae) merupakan herbivora penting dalam rangelands di Amerika Serikat bagian barat. Selain Orthoptera, Ordo Hemiptera adalah yang spesiesnya banyak ditemukan sebagai hama pada kelapa sawit. Ordo Hemiptera termasuk empat ordo terbesar pada kelas hexapoda yang terdiri dari \pm 80.000 spesies, 40 famili dan 5 sub ordo. Hemiptera sebagian besar adalah serangga darat, tetapi banyak yang akuatik. Memakan cairan tumbuh-tumbuhan dan beberapa adalah hama ganas bagi tumbuhtumbuhan budidaya. Selain itu bersifat sebagai pemangsa, dan beberapa bermanfaat bagi manusia (Fauzi et al., 2012). Hemiptera memakan tanaman menggunakan mulutnya yang menusuk dan menghisap untuk mengekstraksi cairan tanaman.

\section{Komposisi Serangga Hama Berdasarkan Lokasi Penelitian}

Kelimpahan tertinggi serangga hama berdasarkan lokasi penelitian terdapat di Nagari Silago. Total jumlah individu yang ditemukan pada Nagari tersebut sebanyak 174 individu dengan 8 famili, 15 spesies. Berikutnya di Nagari Banai ditemukan sebanyak 161 individu dengan 9 famili dan 17 spesies. Kelimpahan terendah terdapat di Nagari IV Koto Nan Dibawuah dimana dikoleksi 55 individu, 4 famili, 11 spesies "(Tabel 2)".

Tabel 2. Komposisi serangga hama pada perkebunan kelapa sawit rakyat

Table 2. Composition of pest insects on smallholder oil palm plantations

\begin{tabular}{lccc}
\hline $\begin{array}{l}\text { Lokasi } \\
\text { Penelitian }\end{array}$ & $\begin{array}{c}\text { Jumlah } \\
\text { Spesies }\end{array}$ & $\begin{array}{c}\text { Jumlah } \\
\text { famili }\end{array}$ & $\begin{array}{c}\text { Jumlah } \\
\text { Individu }\end{array}$ \\
\hline Koto Nan IV & & & \\
Dibawah & 11 & 4 & 55 \\
Silago & 15 & 8 & 174 \\
Banai & 17 & 9 & 161 \\
\hline
\end{tabular}

\section{Kelimpahan Serangga Hama Berdasarkan Lokasi Penelitian.}

Kelimpahan serangga hama di Nagari Silago lebih tinggi dibandingkan Nagari lain disebabkan beberapa faktor. Di Nagari Silago ditemukan tiga spesies serangga hama dengan kelimpahan yang tinggi. Spesies tersebut adalah $S$. splenduns, $T$. marginella dan $B$. Ferruginea (Gambar 2). Selain itu tingginya kelimpahan serangga hama yang di temukan di Nagari Silago disebabkan kondisi lingkungan yang sesuai untuk keberadaan spesies hama. Dimana suhu di lokasi penelitian berkisar antara $25-35^{\circ} \mathrm{C}$, selain itu ketersediaan sumber makanan berupa tumbuhan yang banyak di lokasi penelitian seperti daun-daun rerumputan, kacang-kacangan, dan semak belukar yang tumbuh lebat karena tidak dilakukannya pengendalian oleh pemilik lahan. Faktor lainnya yaitu vegetasi berupa tumbuhan berupa pohon, perdu, dan semak hingga rumput juga berpengaruh sebagai tempat hidup atau bersarangnya serangga hama. Seperti dilaporkan (Efendi, 2016) bahwa kelimpahan suatu serangga di pengaruhi oleh lingkungan yang cocok dan tercukupinya . 


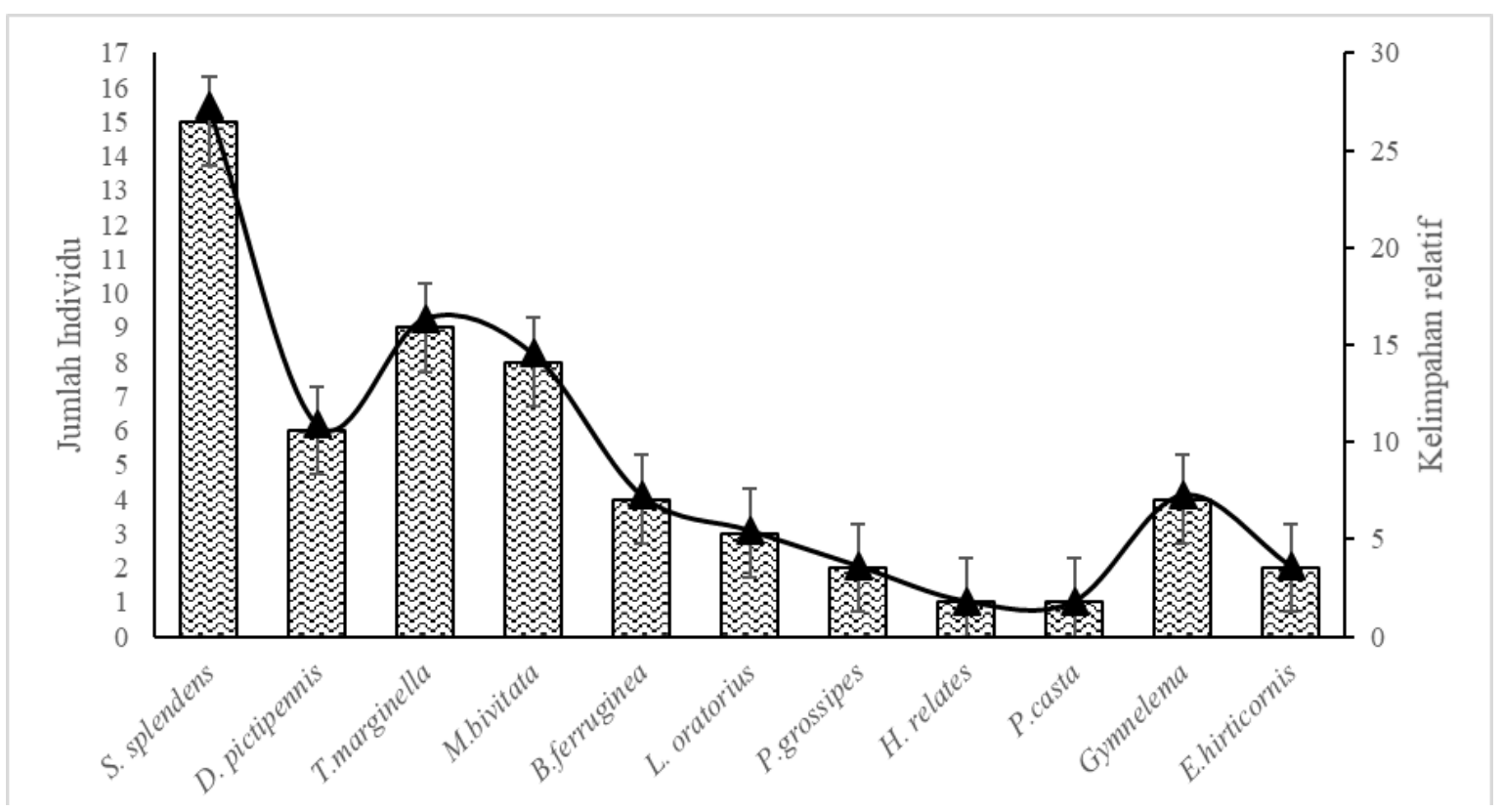

Gambar 1. Kelimpahan populasi hama di Nagari IV Koto Nan Dibawuah Figure 1. The abundance of pest populations in Nagari IV Koto Nan Dibawuah

Menurut (Sun et al., 2015) bahwa ketersediaan tanaman inang dan nilai nutrisi mempengaruhi kelimpahan dan distribusi Orthoptera. Pada saat penelitian vegetasi dan sumber makanan di Nagari Silago lebih tinggi dibandingkan dengan vegetasi dan sumber makanan pada Nagari IV Koto Nan Dibawuah (Gambar 1) dan Nagari Banai (Gambar 3). Hal ini karena di Nagari Silago tidak dilakukannya pengendalian gulma.

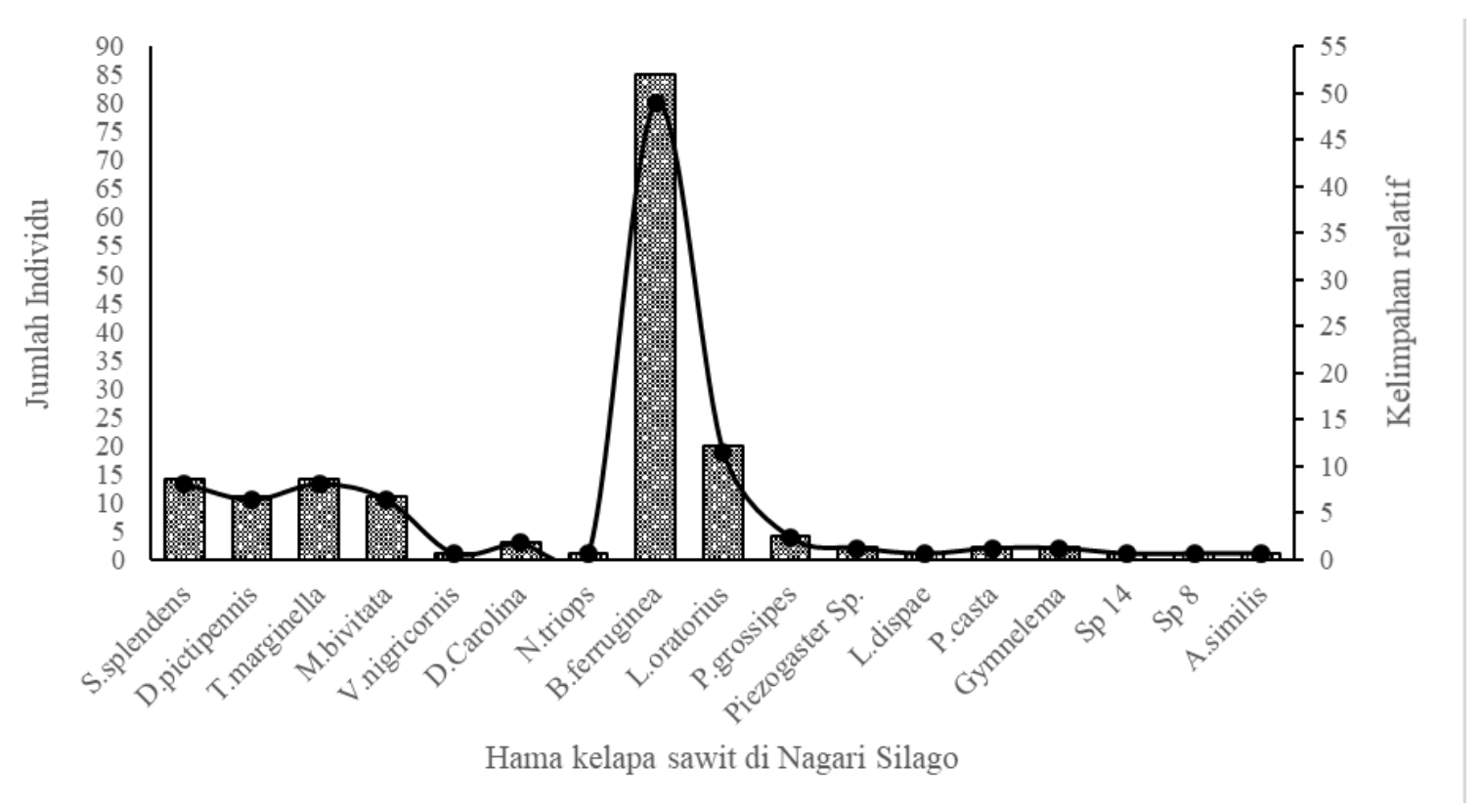

Gambar 2. Kelimpahan populasi hama di Nagari Silago Figure 2. An abundance of pest populations in Nagari Silago 
Bothrogonia ferruginea (Hemiptera : Cicadelidae) merupakan hama pada tanaman kelapa sawit. B. ferruginea paling melimpah ditemukan dari hama lain. $B$. ferruginea adalah serangga yang tergolong dalam kelompok wereng daun (leafhoppers). Dengan struktur mulut tipe haustelata (menusuk mengisap) (Nair, 2000). B. ferruginea menyerang tanaman kelapa sawit dengan cara menghisap cairan daun. Terutama pada daun-daun muda, kondisi ini sesuai dengan lokasi penelitian dimana tanaman kelapa sawit di lokasi penelitian masih berumur 2-5 tahun. Selain itu $B$. ferruginea juga menyerang beberapa tanaman rumputan, semak, maupun pohon. Tingginya kelimpahan $B$. ferruginea yang ditemukan di lahan penelitian juga disebabkan faktor ketersediaan makanan yang melimpah, kurangnya perawatan pada lahan kelapa sawit tersebut sehingga tumbuhnya gulma atau vegetasi dan tanaman lainnya seperti kacang-kacangan yang menjadi inang $B$. ferruginea tersebut.

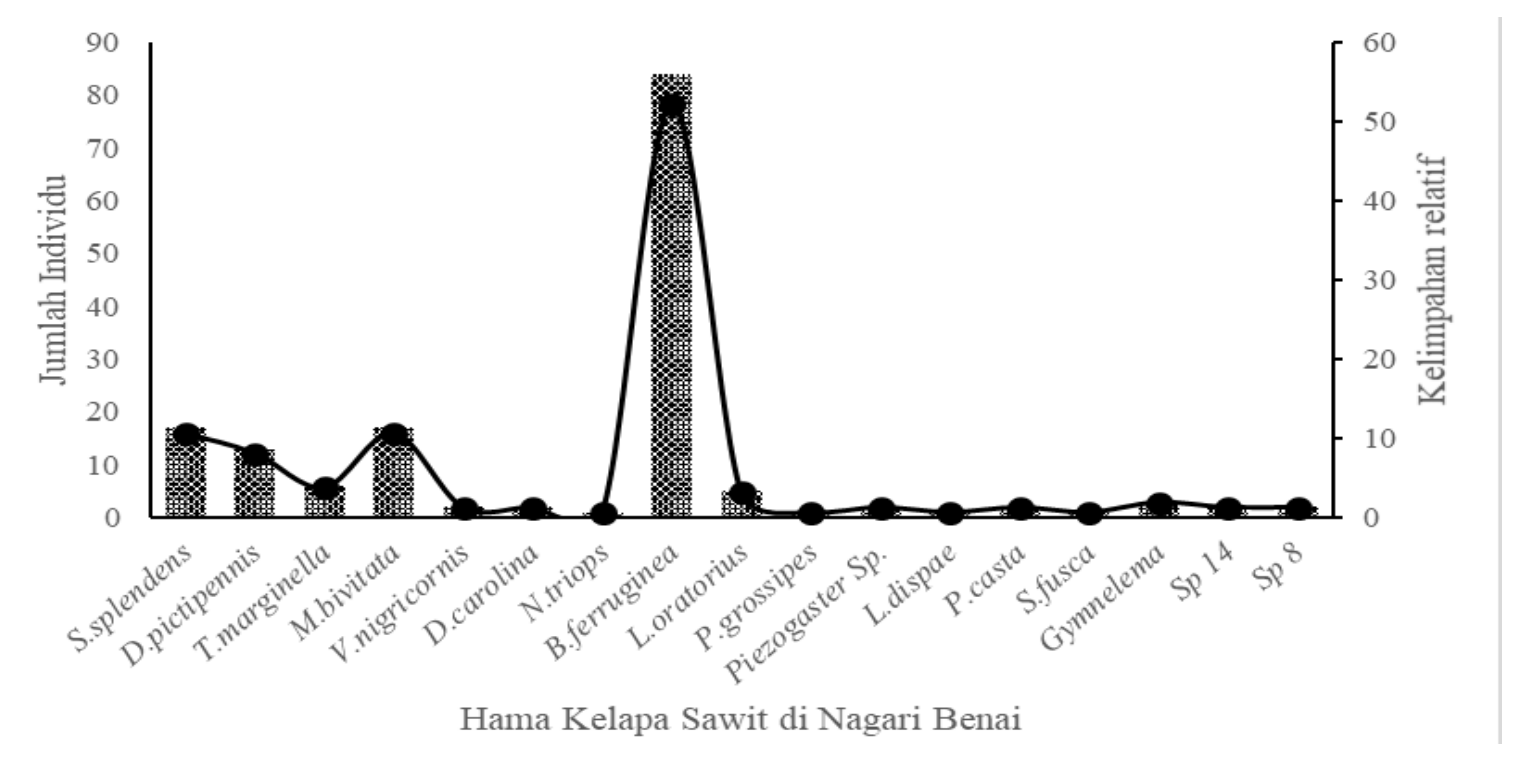

Gambar 3. Kelimpahan populasi hama di Nagari Benai

Figure 3. An abundance of pest populations in Nagari Benai

Dissosteria pictipennis ( Orthoptera: Acrididae) adalah serangga herbivora yang sering merusak dengan cara memakan daun tanaman. Serangga ini menyebabkan daun berlubang-lubang, bentuknya agak bulat. Kadang pada tepi daun terdapat bekas gigitan. Tingginya kelimpahan hama ini karena tersedianya sumber makanan berupa daun-daun. Menurut (Borror et al., 1992). spesies ini menjadi hama potensial pada tanaman budidaya. Hama tersebut tergolong dalam Ordo Ortoptera Famili Acrididae dimana sebagaian besar merupakan hama pada tanaman budidaya salah satunya kelapa sawit. Serangga ini memiliki ciri-ciri khas yaitu memiliki tiga pasang kaki, dan tubuhnya berbuku-buku, memiliki antena yang hampir selalu lebih pendek dari tubuhnya dan juga memiliki ovipositor pendek. Suara yang ditimbulkan beberapa spesies belalang biasanya dihasilkan dengan menggosokan femur belakangnya terhadap sayap depan atau abdomen (disebut stridulasi) atau karena kepakan sayapnya sewaktu terbang, femur belakang umumnya panjang dan kuat yang cocok untuk melompat. Serangga ini umumnya bersayap walaupun sayapnya kadang tidak dapat dipergunakan untuk terbang. Belalang betina umunya berukuran lebih besar dari belalang jantan (Borror et al., 1992). 
Kerusakan Pada Tanaman Kelapa Sawit

Persentase kerusakan akibat hama serangga bervariasi pada masing-masing tanaman kelapa sawit. Persentase kerusakan tertinggi terdapat di Nagari Silago yakni 88,33\%, di Nagari Banai persentase kerusakan yakni $80 \%$, dan persentase kerusakan serangan hama terendah terdapat di Nagari Koto Nan IV Dibawuah yaitu 76,66\%. Pada "(Gambar 4)" . Rata-rata persentase kerusakan pada lokasi pengamatan meningkat setiap pengamatan. Tingkat persentase kerusakan tertinggi terdapat di Nagari Silago disebabkan banyaknya jenis hama dan tingginya kelimpahan masing-masing spesies hama di nagari tersebut. Hama yang dominan di Nagari Silago adalah spesies $B$. ferruginea yang menyerang tanaman dengan cara menghisap cairan daun tanaman. Selain itu, tanaman yang masih muda berumur 2-5 tahun memiliki daun-daun yang masih tergolong muda yang sangat disukai oleh serangga penghisap daun.

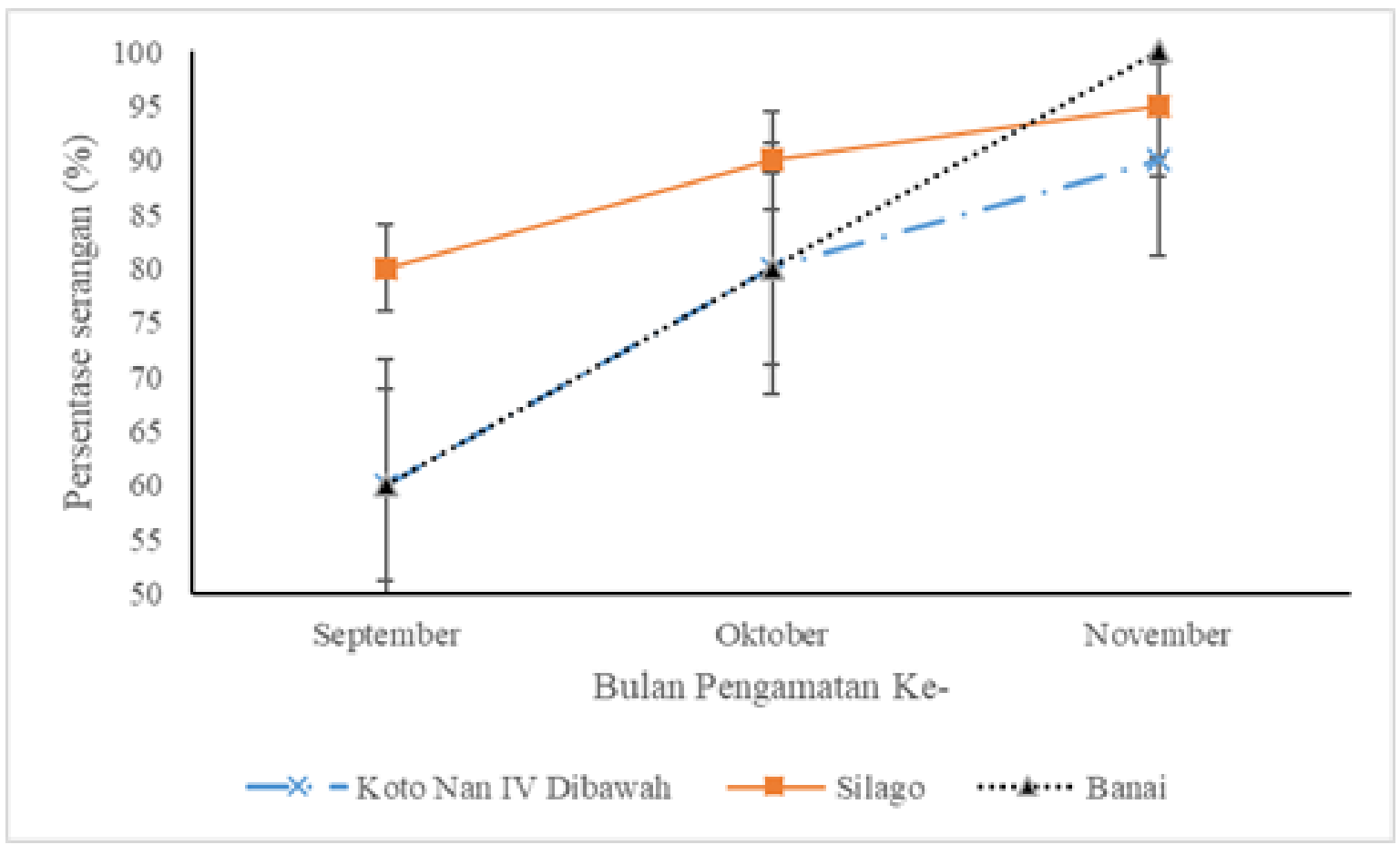

Gambar 4. Persentase serangan hama pada perkebunan kelapa sawit rakyat

Figure 4. Percentage of pest attacks on smallholder oil palm plantations

Tanaman muda juga mempengaruhi kondisi vegetasi yang terdapat didalamnya. Dimana vegetasi berpengaruh terhadap keberadaan suatu hama. Vegetasi merupakan parameter penting untuk mengetahui kenaekaragaman serangga hama di suatu lahan dalam skala besar. Semakin tinggi keanekaragaman vegetasi suatu lahan maka semakin tinggi pula sumber pakan bagi serangga hama sehingga keberadaanya sangat melimpah. Faktor lainnya yaitu gulma yang tumbuh banyak ikut mendorong melimpahnya populasi hama, dimana keberadaan gulma ini juga bisa menjadi sumber makanan bagi hama.

\section{Intensitas Serangan Hama Tiap Tanaman (\%)}

Pada penelitian ini pengamatan intensitas serangan dilakukan secara umum untuk semua jenis hama yang menyerang. Pada penelitian terdahulu pengamatan intensitas serangan dilakukan berdasarkan 
spesies hama tertentu. Berdasarkan pengamatan yang dilakukan diketahui bahwa terdapat peningkatan intensitas serangan pada bulan September sampai November yakni di Nagari Koto Nan IV
Dibawuah dan Banai. Sebaliknya intensitas serangan di Nagari Silago menurun pada bulan Oktober dan November. Bahkan penurunan intensitas serangan tergolong drastis yakni 50,31 menjadi 10,73.

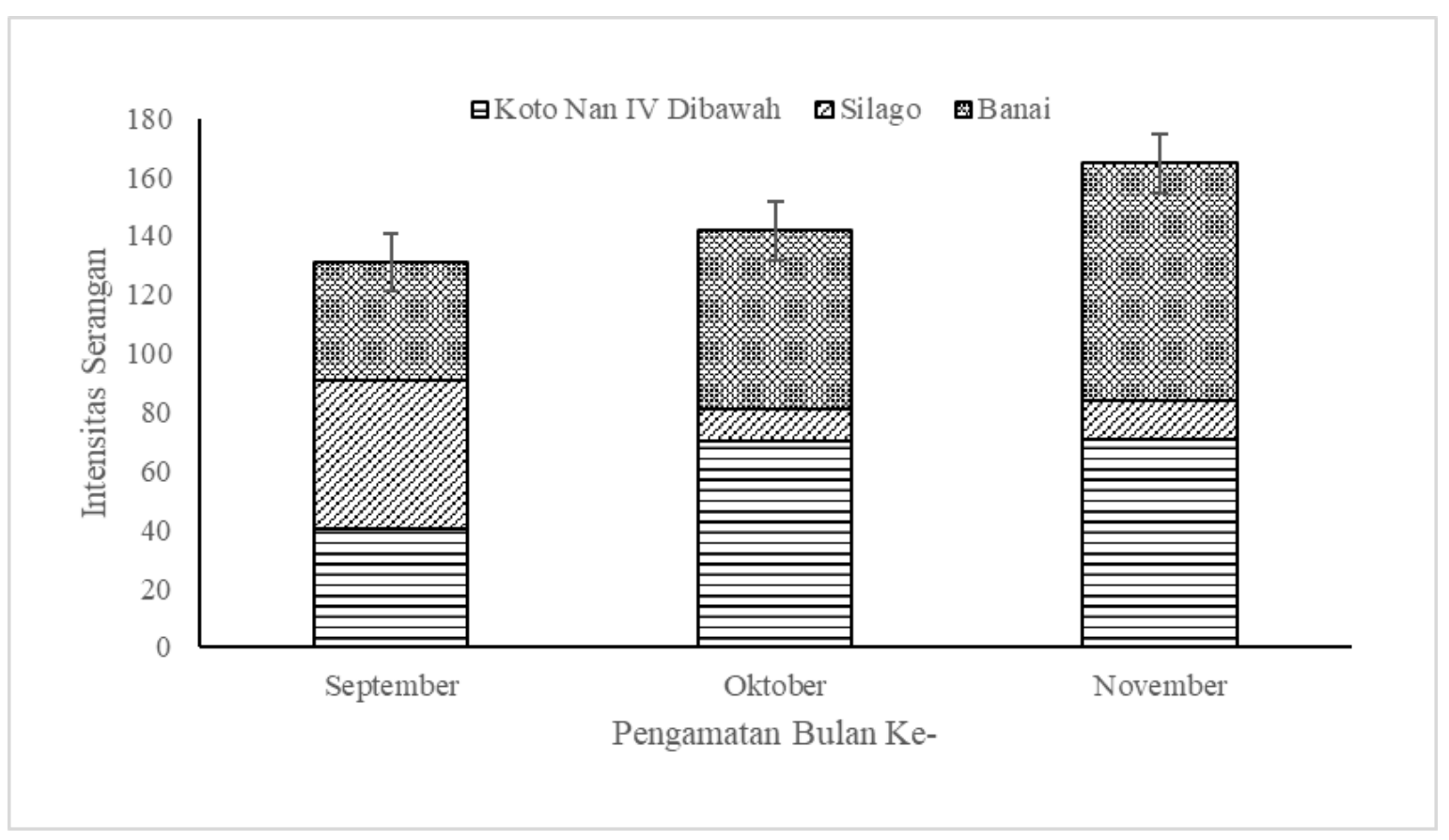

Gambar 5. Intensitas serangan hama pada perkebunan kelapa sawit rakyat

Figure 5. The intensity of pest attacks on smallholder oil palm plantations

Rendahnya rata-rata intensitas serangan dari tingkat kerusakan terjadi karena dalam pengamatan intensitas serangan hama yang di amati adalah tingkat serangan hama pada pelepah tanaman. Walaupun banyak tanaman yang terserang akan tetapi pelepah tanaman yang terserang hanya sedikit. Rata-rata pelepah yang terserang adalah pelepahpelepah pertama dan pelepah yang terletak pada bagian bawah. Pelepah yang terserang tersebut menunjukkan gejala adanya bercak-barcak pada permukaan daun, bekas hisapan dari beberapa serangga dan daun yang berlobang bekas gigitan.

\section{KESIMPULAN}

Pada penelitian yang telah dilakukan, didapatkan serangga hama sebanyak 390 individu yang terdiri dari 4
Ordo, 9 Famili dan 20 spesies. Ordo yang ditemukan dilokasi penelitian yaitu Ordo Orthoptera, Hemiptera, Lepidoptera dan Coleoptera. Ordo Orthoptera paling banyak berperan sebagai hama. Hama paling banyak ditemukan terdapat di Nagari Silago berjumlah 174 individu. Persentase serangan lebih tinggi di Nagari Silago yaitu $88,33 \%$ dan intensitas $9,60 \%$. B. ferruginea (Hemiptera : Cicadelidae) adalah spesies yang memiliki jumlah individu yang lebih tinggi dibandingkan 18 spesies lain yang ditemukan pada perkebunan kelapa sawit.

\section{DAFTAR PUSTAKA}

Badan Pusat Statistik. (2014). Produk

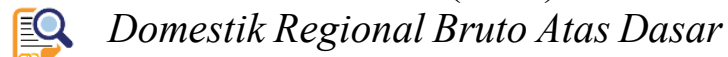
Harga Konstan 2000 Menurut Provinsi, 2000-2013 (Milyar 
Rupiah). https://www.bps.go.id/ dynamictable/2009/06/29/1600/prod uk-domestik-regional-bruto-atasdasar-harga-konstan-2000-menurutprovinsi-2000-2013-milyar-rupiah.html

Badan Pusat Statistik Dharmasraya. 程 (2018). Buku Putih Sanitasi. Pokja Sanitasi Permukiman Kabupaten Dharmasraya.

https://dharmasrayakab.bps.go.id/

Bina, A. (2006). Using a broadly applicable growth-percolation model to design improved biofilters [Dissertation, University of Southern California].

Borror, D. J., Triplehorn, C. A., \& Johnson, N. F. (1992). Pengenalan pelajaran serangga (S. Partosoedjono (Trans.); 6th ed.). Gadjah Mada University Press.

Direktorat Jenderal Perkebunan. (2015). 县 Statistik Perkebunan Indonesia 2014-2016 Komoditas Kelapa Sawit. Direktorat Jenderal Perkebunan, Kementerian Pertanian.

Efendi, S. (2016). Analisis 镐 Keanekaragaman Coccinellidae Predator dan Kutu Daun (Aphididae spp) pada Ekosistem Pertanaman Cabai di Sumatera Barat. Jurnal BiBieT, 1(2), 67-80. https://doi.org/ 10.22216/jbbt.v1i2.1697

Fakhrah. (2016). Inventarisasi insekta 的 permukaan tanah di Gampong Krueng Simpo Kecamatan Juli Kabupaten Bireuen. Jurnal Pendidikan Almuslim, 4(1), 48-52.

Fauzi, Y., Widyastuti, Y. E., Satyawibawa, 尌 I., \& Paeru, R. H. (2012). Kelapa sawit. Penebar Swadaya.
Fielding, D. J., \& Brusven, M. A. (1995).

琶 Grasshopper densities on grazed and ungrazed rangeland under drought conditions in southern Idaho. The Great Basin Naturalist, 55(4), 352358.

Guo, Z.-W., Li, H.-C., \& Gan, Y.-L. (2006). Grasshopper (Orthoptera: Acrididae) biodiversity and grassland ecosystems. Insect Science, 13(3), 221-227. https:// doi.org/10.1111/j.1744-7917.2006. 00086.x

Ingrisch, S. (2008). Zum Einfluß der Feuchte auf die Schlupfrate und Entwicklungsdauer der Eier mitteleuropäischer Feldheuschrec ken (Orthoptera, Acrididae). Deutsche Entomologische Zeitschrift, 30(1-3), 1-15. https://doi.org/10.1002/mmnd.19830 300102

Irwanda BB, Y. (2018). Dampak Budidaya E Tanaman Sela Pada Ekosistem Perkebunan Kelapa Sawit Terhadap Keanekaragaman Serangga Musuh Alami [Skripsi, Universitas Andalas].

Jaganmohan, M., Vailshery, L., \& 嘈 Nagendra, H. (2013). Patterns of Insect Abundance and Distribution in Urban Domestic Gardens in Bangalore, India. Diversity, 5(4), 767-778. https://doi.org/10.3390/ d5040767

Nair, K. S. S. (Ed.). (2000). Insect pests 尌 and diseases in Indonesian forest: an assessment of the major threats, research efforts and literature. Center for International Forestry Research (CIFOR). https://doi.org/ $10.17528 /$ cifor/000700 
Risza, S. (2010). Masa Depan Perkebunan

尌 Kelapa Sawit Indonesia. Penerbit Kanisius.

Safitri, D., Yaherwandi, Y., \& Efendi, S. 钢 (2020). Keanekaragaman Serangga Herbivora Pada Ekosistem Perkebunan Kelapa Sawit Rakyat Di Kecamatan Sitiung Kabupaten Dharmasraya. Menara Ilmu, 14(1), 19-28.

Scientific, C., \& of Entomology, I. R. O. 期 (Australia). D. (1991). The insects of Australia: A textbook for students and research workers (Vol. 2). Cornell University Press.

Simanjuntak, D., Rozziansha, T. A. P., 住 Sudharto, A. S., de Chenon, R. D., Prasetyo, A. E., \& Susanto, A. (2011). Informasi Organisme Pengganggu Tanaman: Setora nitens Walker (Lepidoptera: Limacodidae). Pusat Penelitian Kelapa Sawit, Indonesia.

Sulthoni, A., Siwi, S. S., Subyanto, Lilies E. S., C., \& Sulthoni, A. (1991). Kunci determinasi serangga: program nasional pelatihan dan pengembangan pengendalian hama terpadu. Kanisius.

Sun, T., Liu, Z. Y., Qin, L. P., \& Long, R. J. (2015). Grasshopper (Orthoptera: Acrididae) Community Composition in the Rangeland of the Northern Slopes of the Qilian Mountains in Northwestern China. Journal of Insect Science, 15(1), 6-6. https://doi.org/10.1093/jisesa/ieu171

Sundberg, S. V, Luong-Skovmand, M. H., 钢 \& Whitman, D. W. (2001). Morphology and development of oocyte and follicle resorption bodies in the lubber grasshopper, Romalea microptera (Beauvois). Journal of Orthoptera Research, 10(1), 39-51. https://doi.org/10.1665/10826467(2001)010[0039:MADOOA]2. $0 . \mathrm{CO} ; 2$

Susanto, A., Purba, R. Y., \& Prasetyo, A. E. (2010). Hama dan Penyakit Kelapa Sawit. Volume ke-1. Pusat Penelitian Kelapa Sawit, Indonesia.

Tjiptono, F. (2014). Pemasaran Jasa: 尌 Prinsip, Penerapan dan Penelitian. Andi Publisher.

Ullah, M. I. (2012). Investigations on Eangeland Grasshoppers: Ecoregion Level Distribution, Identification, Feeding Performance, and Vegetation Clipping [Dissertation, University of Nebraska-Lincoln]. 